\title{
Women in the Leadership and Decision Making Processes of Trade Unions in Nigeria: Issues and Prospects
}

\author{
Toyin Adefolaju ${ }^{1}$ \\ ${ }^{1}$ Department of Sociology, Ekiti State University, Ado-Ekiti, Nigeria \\ Correspondence: Toyin Adefolaju, Department of Sociology, Ekiti State University, Ado-Ekiti, Nigeria. Tel: \\ 234-803-855-4307, 234-802-606-7755. E-mail: toyinremi2003@yahoo.com
}

\author{
Received: July 15, 2012 Accepted: September 26, 2012 Online Published: December 31, 2012 \\ doi:10.5539/ass.v9n1p278 \\ URL: http://dx.doi.org/10.5539/ass.v9n1p278
}

\begin{abstract}
Nigerian women had been active in the socio-economic development of their various societies long before colonisation. Their activities situated primarily within their families and communities. Things have however changed in favour of women participation in wage employment and by extension, in trade union activities. This is because membership of the labour force makes one automatic member of the respective organisation's trade union. Being an organisation with patriarchal structures and attitudes, this paper examines the involvement of women in the decision making processes of trade unions in Nigeria. A total of six hundred and forty (640) women in wage employment were chosen for this study through a multi-stage random sampling technique across five industrial unions in the country. Data were generated using the qualitative method wherein copies of a questionnaire were administered on the respondents. This was complemented by in-depth interview sessions with fifteen other female workers. Relevant literatures were reviewed and the study is situated in the pluralist perspective. Findings revealed that while women now play active roles in trade union activities, they are less involved in the decision making processes of their respective trade unions due to inhibiting cultural attitudes and structures. Ameliorative steps that could enhance women greater involvement in the policy-making processes of these trade unions are put forward.
\end{abstract}

Keywords: women, development, trade unions, culture, decision-making

\section{Introduction}

The progress made by women in accessing wage employment is relatively recent. Hitherto, that sector was the exclusive preserve of men who believe that employment outside the home for a woman was a taboo. The woman was therefore expected to remain at home to care for her husband and children. This was seen as an extension of women economic participation which was within the household. They had also been involved in agricultural production and marketing. Albeit all these were not regarded and therefore, not rewarded by the society. However women's ability to make a breakthrough into wage employment has also resulted in their participation in other activities within the industry. As members of the labour force, it became imperative for them to become members of trade unions since union membership is contingent upon wage employment (Yesufu, 1984). Trade unions are organised associations of workers that usually relate with employers on various issues concerning the welfare of their members. They are dominated by men who see them as their power bases. This patriarchal ideology has therefore fostered low women participation in trade union activities.

Nonetheless increased entry/presence in wage employment by women in Nigeria (28 percent of labour force) (NBS, 2009) has also meant their improved participation in trade union activities. This involvement is therefore expected to reflect in women more commitment to the objectives and aspirations of their unions. This therefore raises the question of gender equity and inclusiveness in the leadership and decision-making processes of the unions. As decision making is a very critical function of leadership it is expected that the principle of equality of men and women would be enshrined in the objects of the unions in line with the various international instruments of the United Nations such as the Universal Declaration on Human Rights (1948), the Convention on Human Rights (1976), and the Convention on the Elimination of all forms of Discrimination against Women (1979), among several others.

As an organisation is a collectivity with authority ranks, membership coordinating systems engaged in activities that are usually related to a goal, it follows that the leadership is permanently engaged in the process of making 
decisions geared towards the attainment of set goals. A trade union is an organisation in this fold. Therefore all its members are expected to be involved in making decisions in the running of the organisation. Thus it is pertinent to know the extent to which trade unions involve all its members in its structures and functions. It is also apt to know the extent to which they allow their female members to be involved in the decision making processes, especially in line with avowed universal declaration of human equality. The knowledge of these issues will enable the understanding of the level of women participation in the administration of their unions.

\subsection{Research Questions}

Arising from the foregoing, the following questions have been raised for this study;

1) Are trade unions committed to the principles of internal democracy?

2) To what extent have trade unions upheld the principle of gender equality?

3) Are there barriers inhibiting women access to leadership positions in their unions?

4) How do women attain leadership and therefore decision making positions in their unions?

\subsection{Objectives of the Study}

The main thrust of this study is to assess the place of women in the decision making structures of trade unions. The specific objectives are:

1) To determine the extent of trade union commitment to internal democracy,

2) To ascertain trade union practice of gender equality,

3) To identify, if any, barriers against women attainment of leadership positions in trade unions,

4) To outline ways by which women participation in decision making processes of trade unions can be enhanced.

\section{Brief Literature Review}

In spite of the advancement made in the area of gender empowerment, patriarchy still subsists, maintained and sustained by the socio-cultural system of beliefs and myths (Grint, 1998). This underlies the socialisation process and the gendered education and training both men and women go through from childhood leading to the subordination of women. Women were therefore seen as mere helpers or as commodities or property that could be inherited or disposed of (Amadimue, 1987; Cutrufelli, 1983). Their roles are therefore located in child bearing, rearing and housekeeping (Ofuegbu, 1994; Social Sciences and Reproductive Health Research Network (SSRHN), 2000). There is therefore a universal distinction between male and female on the belief that both are not equal. This has led to a world-wide pattern of division of labour wherein women are given inferior status and therefore subordinate to men.

Patriarchy, as a system of social stratification based on sex, dominates most societies and it provides material advantages to men to the detriment of women on whose path several constraints had been placed. Male's domination of females is therefore the basis of gender relations in these societies where leadership is generally allocated to men while women are socialised to believe that one day, they will be exchanged in marriage. Even when women show the capacity to participate in and contribute to economic development, they are inhibited by various factors including capital, access to land and control over their own resources. It is in this vein that women's work in the home attracts no wage, not highly valued and the housewives who performed them are subordinated to the men who performed paid jobs. The advent of the Industrial Revolution was the turning-point in gender relations as the factory replaced the family as the unit of production with the employment of women in factories (Oakely, 1974; Banks, 1981). The emergence of the school system and later the liberation movement in the 1960s led to the overcoming of the legal, economic and other institutional inequalities in the society. The consequence of this was that women started to shed their subordinate feelings and began to see themselves as being equal to their male counterparts.

The United Nations Organisation (UNO) and its other agencies have been in the forefront in popularising the plight of women. After declaring 1995 as the International Women's Year, it also declared 1976-1985 as the United Nation's Decade for Women, and went ahead to organise four world conferences on women. The conferences centered on issues affecting the status of women in society, viz, violence against women, women's rights and reproductive health, the role of women in agriculture, the status of women in society, the role of women in politics, democratisation and governance. According to UNIFEM (1994) with regard to women, the overall objective of the UNO is to support efforts of women worldwide to achieve their objectives of economic and social development and of equality and by so doing, to improve the quality of life for all. One of the gains of the feminist movement has been the tremendous in-road made into hitherto male-dominated occupations (Clark, 
1992).

Many of these women had entered the labour force in order to achieve the recognition that a good salary and career can offer more so that work had become an avenue for freedom and life fulfillment. The entry of women into wage employment automatically made them to be members of their trade unions in their respective organisations (FRN, 1973). Trade unions are the major groups that represent the interest of employees in an organisation. They emerged from the efforts of workers to seek an improvement on existing working conditions through collective action. They therefore collectively deal with employers on behalf of their members (Kelly, 1998; Fajana, 2000). Unions therefore exist to perform certain functions for their members ranging from economic, social welfare, political, psychological benefits and the opportunity to participate in the managerial functions of the industry. They have also brought about changes in the areas of pay equity, labour standards and worker's fundamental rights.

For Ebbinghaus and Visser (2000), they transformed from social self-help associations, mere bargaining agents or just lobbyists to social movements through which the working class has entered and promoted mass democracy. The ILO (1998) underscores the prime place of unions when it asserts that:

Unions play important roles in guiding and upholding democracy and as defenders of social justice in particular by encompassing women, minorities, consumer groups, the unemployed and the growing ranks of working poor in the sphere of action.

Trade unions however have been challenged on several fronts as they are faced with poor leadership, internal squabbles, inadequate funds and their mismanagement, inactivity and insensitivity to members' interests (Fashoyin, 1984a; Ade-Ajayi, 2003). Fashoyin(1984a), particularly notes that democracy has not thrived within Nigerian trade unions because of the unwillingness of leaders to acknowledge basic constitutional requirements such as respect for human rights and accountability to their members.

Furthermore patrimonial attitudes have been extended to the trade union movement and this has led to its domination by men (Hega,1998). This is more so because the culture, the tradition and the society make it difficult for women to function effectively as trade unionists due to many impediments. Arising from the foregoing allegations of neglect and maginalisation of women in the workplace, this study intends to unveil women's level of participation in trade unions which serve as workers' representatives in the industrial 'parliament'. If industrial democracy is desirable in the workplace it is logical that it should be extended to trade union organisations as an offshoot of industrialisation. What is the extent of women participation within the decision making structures of trade unions? This is the basis for this study.

\section{Theoretical Perspectives: Pluralism}

It developed in western democracies with the aim of explaining the nature and distribution of power in these societies. Its central theme is that power is dispersed among various groups in society. These interest groups have an approximately equal amount of power with which to influence policies. This is on the assumption that the organisation is composed of individuals who constitute distinct sectional groups, each with its own interests, objectives and leadership (Ratman, 2007). Haralambos and Holborn (2000) see pluralism as politics of interest groups with each pressing for its own advantage. As there is no dominant group, politics therefore becomes that of bargaining and compromise. One of such interest groups involved in this are trade unions which are the major groups that represent the interest of workers in any organisation.

Based on the ideology of pluralism, they have empowered the working class to be integrated into the capitalist society consequent upon the fact that conflict between employers and employees has been structured and regulated. The end result of this is the atmosphere of industrial stability as the relationship between capital and labour has moved from adversarial to the level of cooperation in the face of mutual struggle for survival. Pluralism is therefore beneficial to both sides since it leads to a more equal balance of power between both capital and labour and the consequent development of industrial democracy.

The formation of worker's interest group (trade unions) signaled the beginning of democracy in industry with the groups representing the workers. However the effectiveness of the interest groups depend on both employers and State's approval, and represents a major step towards industrial democracy and the institutionalisation of conflict. In line with this, trade unions have been effective in providing economic benefits and rights to their members. This has manifested in increased earnings, improvements in working conditions, longer and paid holidays and shorter working week, among several others, which workers now enjoy.

\section{Research Methods}

This work focusses on internal democracy and governance within trade unions in Nigeria. It is particularly about 
women's access to decision making positions in the trade unions. A total of six hundred and forty (640) female respondents from five industrial unions were selected using multi-stage random sampling technique. Data were gathered from the respondents using both quantitative and qualitative methods. For the qualitative data, in-depth interviews were conducted in order to have a deep understanding of the meanings of the questions. Fifteen respondents were chosen from each union for the in-depth interviews. For the quantitative data, an open- and close-end questionnaire was utilised. Data from both the qualitative and quantitative methods were analysed accordingly while data from the in-depth interviews were analysed through content analysis.

\section{Discussion of Findings.}

This research is about women's involvement in the decision making structure of trade unions in Nigeria.

Table 1 . Whether they belong to trade unions

\begin{tabular}{lll}
\hline Response & Respondents $(\mathrm{N}=640)$ & Percentage \\
\hline Yes & 498 & 77.8 \\
No & 93 & 14.5 \\
No Response & 49 & 7.7 \\
Total & 640 & 100 \\
\hline
\end{tabular}

Data in Table 1. shows that close to 80 percent of the respondents belong to trade unions while about 20 percent were not sure of their membership status. This high number of union membership is no doubt the consequence of their being in wage employment which is a necessary condition for trade union membership. In addition, trade union membership is mandatory for all Nigerian workers in line with the provisions of Trade Unions Act (Amendment) 1996, except a worker opts out on his own. Beyond the fact of union membership, the study sought to know if the respondents thought they were active members in their unions.

Table 2. Whether they are active members

\begin{tabular}{lll}
\hline Response & Respondents $(\mathrm{N}=640)$ & Percentage \\
\hline Yes & 349 & 54.5 \\
No & 208 & 32.5 \\
No Response & 83 & 13.0 \\
Total & 640 & 100 \\
\hline
\end{tabular}

Table 2. shows that 349 respondents, representing about 55 percent of the respondents claimed to be active members of their respective unions while about 30 percent of them believe that they were not active.

Table 3. Level of participation in the union

\begin{tabular}{lll}
\hline Level & No $(\mathrm{N}=289)$ & Percentage \\
\hline Attend meetings regularly & 69 & 23.8 \\
Pay dues & 189 & 65.5 \\
Union EXCO members & 31 & 10.7
\end{tabular}

Table 3 gives a picture of the level of participation of respondents in union matters. Most of the respondents, 189 (about 66 percent) stated that their participation was at the level of paying 'dues'. Sixty-nine (69), that is about 24 percent, claimed to attend union meetings regularly, while 31 respondents (about 11 percent) claimed to be executive members of their unions thus making it mandatory for them to participate in the union affairs.

Table 4. Whether they occupy a union post

\begin{tabular}{lll}
\hline Response & Respondents $(\mathrm{N}=498)$ & Percentage \\
\hline Yes & 47 & 9.5 \\
No & 451 & 90.5 \\
No Response & Nil & Nil \\
Total & 498 & 100 \\
\hline
\end{tabular}

With regard to union positions occupied by women in the unions, Table 4 , shows that a very small number of the respondents, 47 (9.5 percent) claimed to occupy any position in all the unions, while a majority- 451 , that is, 90.5 
percent- are not members of the executive of any of the unions. The study further examined the respondents who claimed union positions and it revealed that most of them are in positions at the lower rungs of union structure.

Table 5. Union position occupied by women

\begin{tabular}{lll}
\hline Post & No $(\mathrm{N}=47)$ & Percentage \\
\hline Chairman & 2 & 4.2 \\
Vice Chairman & 2 & 4.2 \\
Secretary & 4 & 8.4 \\
Treasurer & 10 & 21.2 \\
Social Welfare Officer & 14 & 30 \\
P.R.O & 8 & 17 \\
Ex-officio & 7 & 15 \\
\hline
\end{tabular}

Table 5 shows that majority of the women (39) had held one of these four positions in the unions- Treasurer, Social Welfare Officer, Public Relations Officer and Ex-Officio member ( 83 percent), leaving the top-most positions- Chairman, Vice-Chairman and Secretary for their men-folk. The study further probed into the highest posts women had attained in the unions. This is with a view to ascertaining the level of equity in the unions and this is reflected in Table 6.

Table 6. Highest position occupied by women

\begin{tabular}{lll}
\hline Post & No $(\mathrm{N}=519)$ & Percentage \\
\hline Chairman & 3 & 0.5 \\
Vice Chairman & 8 & 1.5 \\
Secretary & 10 & 2.0 \\
Treasurer & 58 & 11.0 \\
Social Welfare Officer & 309 & 59.6 \\
P.R.O & 65 & 12.5 \\
Ex-officio & 66 & 12.8 \\
\hline
\end{tabular}

Table 6 , shows that the position mostly occupied by women is that of Social Welfare Officer as claimed by 309 respondents, that is about 60 percent. The mainly 'executive positions' in the unions- Chairman, Vice-Chairman and Secretary- had only been held by 21 respondents, that is, 4 percent

Table 7. Whether a woman can lead the union

\begin{tabular}{lll}
\hline Woman leadership & No $(\mathrm{N}=567)$ & Percentage \\
\hline Yes & 474 & 83.5 \\
No & 93 & 16.5 \\
\hline
\end{tabular}

An overwhelming number of respondents (84 percent) as shown in Table 7, asserted that women can lead unions and be more active but for various factors which are noted below. A respondent notes:

There is nothing in a union that a woman cannot lead. We (women) possess leadership qualities equally as men if not more. I believe what a man can do a woman can do better. That women are few at the leadership levels our unions is a deliberate action. Men can't tolerate a woman as their boss. It is part of the action to keep the woman down. If men say it is difficult, let them try the women. We see organisations where women are prominent and they are doing fine.

Table 8. Obstacles against female participation in union activities

\begin{tabular}{lll}
\hline Obstacles & No $(\mathrm{N}=640)$ & Percentage \\
\hline Family and domestic responsibilities & 153 & 23.9 \\
Culture of male domination & 144 & 22.5 \\
Meeting time and venue & 237 & 37.0 \\
Low numerical strength & 106 & 16.6 \\
\hline
\end{tabular}

Table 8. identifies the factors that inhibit women participation to include: family and domestic responsibilities 
(24 percent), culture of male domination (22 percent), time and venue of union meetings ( 37 percent) leading to a low numerical strength (17 percent) of women in the unions. From the in-depth interviews, it was gathered that union meetings are held after working hours, late into the night, a period that is not convenient for women members as they are required to tend to family and domestic issues. Furthermore they claimed that meetings are held in hotels and this runs contrary to women cultural values in Nigeria. This accounts for low attendance and voting of women at union meetings. One respondent lamented thus:

When I get home in the evening, I prepare food for the household, look after the children and husband's needs. By the time I finish the only thing I could do is to sleep. So if I'm even interested in union activities, I can't attend because while they are meeting, I am asleep

Table 9. Frequency of attending meetings by women

\begin{tabular}{lll}
\hline Variables & No $(\mathrm{N}=640)$ & Percentage \\
\hline Very often & 88 & 13.8 \\
Often & 115 & 18.00 \\
Seldom & 208 & 32.5 \\
Don't attend & 229 & 35.7 \\
\hline
\end{tabular}

Table 9. gives the picture of respondents' attendance of union meetings. A significant proportion of them 437, about (68 percent) hardly attend meetings. This is no doubt a fallout of various obstacles as identified in Table 8 . Since they rarely attend meetings, it follows that most decisions are taken without the respondent's contributions. The implication of this is that women are not involved where decisions crucial to members of the unions are taken. This thus shut them away from the sphere of collective bargaining issues relating and peculiar to the female worker such as pay parity, maternity benefits, child care, training etc.

Table 10. Frequency of voting at union meetings

\begin{tabular}{lll}
\hline Frequency of voting & No $(\mathrm{N}=640)$ & Percentage \\
\hline Very often & 82 & 12.8 \\
Often & 113 & 17.7 \\
Sometimes & 210 & 32.8 \\
Never & 235 & 36.7
\end{tabular}

Having a say in one's organisation is a key element of democracy (Arikewuyo, 2001). This right is usually exercised by being involved in the election of the leadership of the organisation. Table 10 shows that respondents are not in the reckoning in this regard as only a very few of them 82 (13 percent) claimed to be always present during elections while a significant proportion, 445 , about ( 69 percent) are hardly available during such elections. This will further entrench male domination of the unions as they only are mostly available during elections. The study however revealed an apparent loss of confidence in the electoral process in trade unions as stated by a respondent:

We women don't need to vote at elections. This is because before the elections, those who will occupy particular positions are already determined. There is what they call 'election before election'. Why should women bother themselves when their votes don't count

Table 11. Frequency of whether ever contesting elections

\begin{tabular}{lll}
\hline Contested & No $(\mathrm{N}=640)$ & Percentage \\
\hline Yes & 103 & 16.8 \\
No & 537 & 83.2 \\
\hline
\end{tabular}

Table.11 gives a response that appears to derive from the previous answer. Only 103 (about 17 percent) of the respondents claimed to have contested an election previously in the unions, while 537 (83 percent) stated that they had never. The respondents seemed scared of contesting elections since according to them the outcomes are usually predetermined as stated by this respondent:

I can never contest any election in the union. We always knew who will win an election. The men meet and say this and this will occupy certain positions, spend money and that is it. I don't have the money to waste and elections are merely to ratify the leaders candidates. 
A further probe into the participatory activities of respondents in the unions centered on their awareness of the decision-making pattern in their unions and this is shown in the table below;

Table 12. How decisions are taken in the unions

\begin{tabular}{lll}
\hline Decision making pattern & No $(\mathrm{N}=640)$ & Percentage \\
\hline Union leaders decide & 311 & 48.6 \\
Committees of union & 63 & 9.8 \\
Meeting of all workers & 52 & 8.2 \\
Combination of many & 90 & 14.0 \\
Don't know & 124 & 19.4 \\
\hline
\end{tabular}

Table 12 indicates that 49 percent asserted that 'union leaders' take decisions, while 'committees of union members' take decisions (9.8 percent). About 8 percent of respondents stated that decisions are taken at the Congress level by all union members, while a significant number (19 percent) claimed not to know how decisions are taken. It is apparent from the responses that leaders who are mostly men, monopolised the decision-making process in the unions.

\section{Concluding Remarks}

Women's entry into the labour market had enabled them to contribute their quota to the development of their environment and significantly, to take part in other activities within industry. Their participation has therefore given them the opportunity to join trade unions which hitherto had been the preserve of men. This study is therefore about the participation of women in these unions in Nigeria especially in the context of their relevance in their decision making processes. There is no doubt that women are committed to trade unionism even though they are moderated by their cultural roles especially responsibility for marital and domestic duties. This study has revealed that patriarchal values dominate the trade union environment arising from the little cooperation, encouragement and support women experience in union works especially from their men-folks. It is also apparent in the study that these unions lack the ethics and ethos of participatory democracy as they are oblivious of the fact that democratic styles of leadership are more likely to produce effective group performance.

Based on the foregoing, the following recommendations are put forward to enhance the participation of women in the decision making structure of trade unions.

1) There is the need to recognise women as partners in progress and that their efforts are geared towards complementing men's. Thus patriarchal attitudes and practices that tend to reinforce women subordination should be discarded. This change of attitude from both men and women could for instance lead to a more equitable distribution of family responsibilities which would enable women to take up positions of responsibilities in trade unions.

2) Trade unions as the statutory vehicle for the articulation and protection of the collective interests of workers should go beyond merely professing the ideals of democracy by creating a level playing field for all members to take part in the decision making apparatus of trade unions. This is more so that no organisation can be productive without the active, responsible and selfless involvement of all its members.

3) In a bid to integrate women, trade unions should go beyond the cosmetics of creating 'Women Wings' where they thought women could realise their trade union aspirations. This keeps women in the tributaries of trade union activities and foster representation without participation. Mainstreaming entails integration of all members into the main structure of the organisation with equal and competitive processes.

4) Unions should create the conducive environment for women members to participate in their activities and programmes by holding them at periods and venues easily and culturally accessible to women. For example, these activities could be held during working hours (break periods, perhaps) and venues such as union secretariat, company premises or public conference halls.

\section{References}

Ade-Ajayi, J. F. (2003). The Role of Management in University Governance: A paper presented at the Biennial Seminar of the National Association of Pro-Chancellors of Nigeria Universities, held on 14 and 15 January.

Amadimue, I. (1987). Male Daughters, Female Husband: Gender and Sex in an African Society. London, Zed Books

Arikewuyo, M. O. (2001). Industrial Democracy and Employees Participation in Organisation. In J. Obikoya et 
al. (Eds.), Human Resources Management and Industrial Relations in Nigeria. Ago-Iwoye, Center for Sandwich Programmes.

Banks, O. (1981). Faces of Feminism: A study of Feminism as a Social Movement. London, Martin Robertson and Co Ltd.

Clark, E. (1992). Breaking Gender Management Monopolies. Management in Nigeria, 28(4), 10-14.

Cutrufelli, M. R. (1983). Women of Africa: Roots of Oppression. London, Zed Press.

Ebbinghaus, B., \& Visser, J. (2000). The Societies of Europe: Trade Unions in Western Europe Since 1945. Basingstoke, Macmillan Reference Ltd.

Fajana, S. (2000). Industrial Relations in Nigeria Theory and Features. Lagos, Labofin and Co.

Fashoyin, T. (1984a). Internal Dynamics in Nigeria. Paper Series; Department of Industrial Relations and Personnel Management, Lagos, University of Lagos.

FRN. (1973). Trade Unions Act 1973, Lagos, Government Printer.

Grint, K. (1998). The Sociology of Work. Cambridge Polity Press.

Haralambos, M., \& Holborn, A. (2000). Sociology; Themes and Perspectives. London, Collins Publishers.

Hega, M. D. (1998). Women and Trade Unions: Context, The Gains and the Road Ahead: The Philipine Experience. Retrieved from http://library.fes.De/fultext/lez/011/0001htm

ILO. (1998). World Labour Report 1997-1998. Geneva, International Labour Organization.

Kelly, J. (1998). Rethinking Industrial Relations: Mobilization, Collectivism and Long Waves. London, Routledge.

NBS. (2009). Social Statistics in Nigeria. Abuja. Federal Republic of Nigeria.

Oakley, A. (1914). House Wife. London, Allen Lane.

Ofeogbu, S. (1994). Gender Equality and Empowerment of Women. Lagos. Bond Associates.

Ratnam, V. C. S. (2007). Industrial Relations. New Delhi, Oxford University Press.

Social Sciences and Reproductive Health Research Network (SSRHRN). (2001). Gender Socialization and Male Responsibility in the Family. Annals of the Social Science Academy of Nigeria, No 13 January-December.

UNIFEM NEWS. (1994, June). Unifem News.

Yesufu, T. M. (1984). The Dynamics of Industrial Relations: The Nigerian Experience. Ibadan, Ibadan University Press. 